\title{
ANALISIS PENGARUH KINERJA KEUANGAN, FIRM SIZE DAN CASH FLOW TERHADAP RETURN SAHAM PERUSAHAAN MANUFAKTUR DI INDONESIA
}

\author{
Farah Margaretha Leon \\ Fakultas Ekonomi dan Bisnis, Universitas Trisakti \\ farahmargaretha@trisakti.ac.id \\ Ricky \\ Fakultas Ekonomi dan Bisnis, Universitas Trisakti \\ Diterima 1 Agustus 2017, Disetujui 18 Agustus 2017
}

\begin{abstract}
Abstrak
Tujuan dari penelitian ini adalah untuk menganalisis seberapa besar pengaruh kinerja keuangan, firm size, cash flow terhadap EPS pada perusahaan manufaktur yang terdaftar di Bursa Efek Indonesia. Analisis data yang digunakan dalam penelitian ini adalah uji t untuk uji parsial dan uji $F$ untuk pengujian secara simultan. Hasil penelitian ini menyimpulkan bahwa data telah memenuhi asumsi klasik. Secara parsial, analisis regresi menunjukkan bahwa NPM, ROE, total asset, dan firm size memiliki dampak positif dan signifikan terhadap EPS. Namun, current ratio, debt to equity ratio, price book value, dan variabel cash flow tidak mempengaruhi EPS. Hasil penelitian ini dapat digunakan investor sebagai salah satu dasar pengambilan untuk berinvestasi di pasar modal, dan bagi perusahaan dapat memberikan informasi agar para investor tertarik untuk menginvestasikan modal mereka.
\end{abstract}

Kata kunci : rasio keuangan, ukuran perusahaan, arus kas, laba perlembar saham.

\section{Abstrack}

The purpose of this study is to analyze how much influence financial ratios, firm size, cash flow from operations to EPS on companies listed in Indonesia Stock Exchange. Analysis of the data used in this study is to test the t test and the partial F test for simultaneous testing. Results of this study concluded that the data meets the classical assumptions. Partially, regression analysis showed that NPM, ROE, total assets, and firm size has a positive and significant impact on EPS. However, current ratio, debt to equity ratio, price -book value, and the variable cash flow from operations does not affect EPS. Results of this study can be used by investors as one of the basic decision to invest in the stock market, and the company can provide information that investors are interested to invest their capital.

Keyword: financial ratios, firm size, cash flow, earning per share. 


\section{PENDAHULUAN}

Krisis ekonomi global yang terjadi tahun 2008, menyebabkan banyak perusahaan serta lembaga keuangan yang bertumbangan. Salah satu alternatif bagi perusahaan untuk mendapat dana atau tambahan modal adalah melalui pasar modal. Pasar modal adalah sarana yang mempertemukan penjual dan pembeli dana. Tempat penawaran penjualan efek ini dilaksanakan berdasarkan satu lembaga resmi yang disebut bursa efek (Tjiptono dan Hendy, 2011).

Perdagangan surat berharga merupakan cara untuk menarik dana masyarakat dalam hal ini investor untuk mengembangkan perekonomian dimana dana tersebut adalah modal yang dibutuhkan perusahaan untuk memperluas usahanya. Dengan dijualnya saham di pasar modal berarti masyarakat di beri kesempatan untuk memiliki dan mendapatkan keuntungan. Dengan kata lain pasar modal dapat membantu pendapatan masyarakat. Motif dari perusahaan yang menjual sahamnya untuk memperoleh dana yang akan digunakan dalam pengembangan usahanya dan bagi pemodal adalah untuk mendapatkan penghasilan dari modalnya.

Pasar modal di Indonesia memiliki prospek yang sangat menarik, dikarenakan pertumbuhan ekonomi makro di Indonesia yang terbilang cukup baik, iklim usaha yang kondusif serta situasi politik dan keamanan yang aman. Hal tersebut menambah gairah para investor untuk berinvestasi di Indonesia. Dalam berinvestasi umumnya para investor mengharapkan manfaat yang akan dihasilkan dalam bentuk Earning Per Share. Karena Earning Per Share dapat menunjukkan tingkat kesejahteraan perusahaan, jadi apabila Earning Per Share yang dibagikan kepada para investor tinggi maka menandakan bahwa perusahaan tersebut mampu memberikan tingkat kesejahteraan yang baik kepada pemegang saham, sedangkan Earning Per Share yang dibagikan rendah maka menandakan bahwa perusahaan tersebut gagal memberikan kemanfaatan sebagaimana diharapkan oleh pemegang saham. Selanjutnya Nikolai et al (2010) menyatakan bahwa Earning Per Share sering dianggap sebagai ukuran terbaik dalam menilai kinerja korporasi, terutama bagi para pemegang saham/investor.

Perusahaan juga perlu menarik perhatian para investor agar para investor mau menginvestasikan uang mereka pada perusahaan mereka, karena dalam melakukan investasi saham para investor tentunya perlu mencermati laporan keuangan perusahaan yang dapat diolah menjadi informasi yang bermanfaat dalam proses pengambilan keputusan para investor. Dengan kata lain laporan keuangan di rancang untuk membantu para pemakai laporan untuk mengidentifikasi hubungan variabelvariabel dari laporan keuangan.

Investor memutuskan seberapa besar mereka bersedia untuk membeli saham suatu perusahaan didasarkan pada besaran Earning Per Share perusahaan tersebut. Oleh sebab itu perusahaan harus pula memberikan nilai Earning Per Share yang menarik, sehingga para investor bersedia berinvestasi pada suatu perusahaan tertentu. Oleh sebab itu mengetahui faktor yang mempengaruhi Earning Per Share menjadi penting. Rasio keuangan dan aliran kas merupakan instrumen yang dapat memprediksi pendapatan dan kinerja dari suatu perusahaan. Dalam beberapa penelitian rasio keuangan terbukti secara signifikan dapat mempengaruhi Earning Per Share. Taani dan Banykhaled (2011) mengemukakan bahwa Profitability Ratio (ROE), Market ratio (PBV), Cash Flow from Operation, dan Leverage Ratio (DER) mempunyai dampak yang signifikan terhadap Earning Per Share pada Amman Stock Market. Selanjutnya Pouraghajan et al (2013) menyimpulkan bahwa rasio keuangan (net profit margin, return on equity, current ratio, debt ratio, total asset turnover ratio, market value to book value ratio) dan firm size mempengaruhi Earning Per Share secara signifikan pada Tehran Stock Exchange. Begitu pula dengan firm size semakin besar ukuran perusahaan tersebut maka semakin besar pula kemampuan perusahaan tersebut dalam menghasilkan laba, Daniati dan Suhairi (2006) menyimpulkan arus kas operasi dan firm size berpengaruh positif terhadap return, Dewi (2012) menyimpulkan bahwa net profit margin dan firm size mempunyai pengaruh signifikan terhadap earning perusahaan. Dan juga jumlah arus kas operasional yang memadai bagi operasional perusahaan mampu meningkatkan return saham (Pradhono dan Yulius, 2004).

Tujuan dari penelitian ini adalah untuk menganalisis seberapa besar pengaruh kinerja keuangan (NPM, ROE,CR, SER, TATO, PBV), firm size, cash flow from operation terhadap earning per share pada perusahaan manufaktur yang terdaftar di Bursa Efek Indonesia pada tahun 20092011.

\section{KAJIAN TEORI}

\section{Kerangka Pemikiran}

Nikolai et al (2010) menyatakan bahwa Earning 
Per Share sering dianggap sebagai ukuran terbaik dalam menilai kinerja korporasi, terutama bagi para pemegang saham/investor. Earning Per Share sangat relevan bagi para penggunanya dalam mengevaluasi laba atas investasi dan risiko korporasi. Lasher (2010) mengemukakan Earning Per Share adalah faktor utama dalam menentukan nilai saham perusahaan. Para Investor memutuskan seberapa besar mereka bersedia untuk membeli saham suatu perusahaan didasarkan pada besaran Earning Per Share perusahaan tersebut. Earning Per Share yang tumbuh merupakan tanda yang sangat positif. Sementara Earning Per Share yang stagnan atau menurun dapat menyebabkan harga saham tertekan. Earning Per Share sangat penting serta ia sangat terkait dengan Price Earning Ratio yang merupakan hal pertama yang dilihat investor dalam mempelajari potensi investasi.

Dalam beberapa penelitian terdapat beberapa faktor yang secara signifikan mempengaruhi Earning Per Share. Faktor-faktor tersebut adalah rasio keuangan, firm size, dan cash flow from operation. Rasio keuangan terbukti secara signifikan dapat mempengaruhi Earning Per Share. Taani dan Banykhaled (2011) mengemukakan bahwa Profitability Ratio (ROE), Market ratio (PBV), Cash Flow from Operation/Sales, and Leverage Ratio (DER) mempunyai dampak yang signifikan terhadap Earning Per Share pada Amman Stock Market.

Pouraghajan et al (2013) menyimpulkan bahwa rasio keuangan (net profit margin, return on equity,current ratio, debt ratio, total asset turnover ratio, market value to book value ratio) dan firm size mempengaruhi earning per share secara signifikan pada Tehran Stock Exchange. Begitu pula dengan firm size. Semakin besar ukuran perusahaan tersebut maka semakin besar pula kemampuan perusahaan tersebut dalam menghasilkan laba, Daniati dan Suhairi (2006) menyimpulkan arus kas operasi dan firm size berpengaruh positif terhadap return. Dewi (2012) menyimpulkan bahwa net profit margin dan firm size mempunyai pengaruh signifikan terhadap earning perusahaan. Dan juga jumlah arus kas operasional yang memadai bagi operasional perusahaan mampu meningkatkan return saham (Pradhono dan Yulius, 2004).

\section{Pengembangan Hipotesis Rasio keuangan}

Kinerja Keuangan sebuah perusahaan lebih banyak di ukur berdasarkan rasio-rasio keuangan selama satu periode tertentu. Rasio keuangan dapat membantu dalam mengidentifikasikan kekuatan dan kelemahan keuangan perusahaan. Rasio keuangan terbukti secara positif dan signifikan dapat mempengaruhi Earning Per Share. Taani dan Banykhaled (2011) mengemukakan bahwa Profitability Ratio (ROE), Market ratio (PBV), dan Leverage Ratio (DER) mempunyai dampak positif yang signifikan terhadap Earning Per Share pada Amman Stock Market.

Dwi et al (2009) yang juga mengemukakan bahwa profitability, turnover dan market ratio mempunyai dampak positif yang signifikan terhadap stock return. Begitu pula dengan penelitian dari Pouraghajan et al (2013) menyimpulkan bahwa rasio keuangan (net profit margin, return on equity, current ratio, debt ratio, total asset turnover ratio, market value to book value ratio) mempengaruhi earning per share secara positif dan signifikan pada Tehran Stock Exchange. Berdasarkan penelitian terdahulu, maka dapat ditarik hipotesis sebagai berikut:

$\mathbf{H}_{1}$ :Terdapat pengaruh yang positif dan signifikan dari kinerja keuangan terhadap earning per share.

\section{Firm Size}

Ukuran perusahaan/Firm size menggambarkan besar kecilnya suatu perusahaan yang dapat diukur dengan melihat besar kecilnya penjualan, jumlah modal atau juga melalui total aktiva yang dimiliki oleh sebuah perusahaan. Pengaruh ukuran perusahaan dengan struktur keuangan berdasarkan pada kenyataan bahwa semakin besar perusahaan, maka semakin besar pula kesempatannya untuk menanamkan modalnya pada berbagai jenis usaha, lebih mudah memasuki pasar modal, memperoleh penilaian kredit yang tinggi dan membayar bunga yang lebih rendah untuk dana yang dipinjamnya. Dalam beberapa penelitian ukuran perusahaan/ firm size terbukti berpengaruh secara signifikan dan positif terhadap earning per share. Dalam penelitian Ruwanti dan Devina (2012) menyimpulkan bahwa firm size berpengaruh positif dengan earning per share. Daniati dan Suhairi (2006) menyimpulkan pula bahwa firm size berpengaruh positif terhadap return. Begitu pula Johnson et al. (2003) ukuran perusahaan terbukti signifikan mempengaruhi earning per share secara positif yang tercermin dari peningkatan profitabilitas perusahaan. Berdasarkan penelitian terdahulu, maka dapat ditarik hipotesis sebagai berikut:

$\mathbf{H}_{2}$ :Terdapat pengaruh yang positif dan signifikan dari 
firm size terhadap earning per share.

Cash Flow from Operation / Arus Kas dari Aktivitas Operasi

Jumlah arus kas yang berasal dari aktivitas operasi merupakan indikator yang menentukan apakah dari operasinya perusahaan dapat menghasilkan kas yang cukup untuk melunasi pinjaman, memelihara kemampuan operasi perusahaan, membayar dividen dan melakukan investasi baru. Maka jumlah arus kas operasional yang memadai bagi operasional perusahaan mampu meningkatkan return saham (Pradhono dan Yulius, 2004).

Hal ini diperkuat pula dengan penemuan dari Daniati dan Suhairi (2006) menyimpulkan arus kas operasi dan firm size berpengaruh positif terhadap return. Begitu pula Triyono dan Hartono (2000) dalam penelitiannya mengenai hubungan kandungan informasi arus kas, komponen arus kas dan laba akuntansi dengan harga dan return saham menemukan bahwa arus kas dari aktivitas operasi mempunyai hubungan yang signifikan dengan harga saham. Dipertegas lagi dalam penelitian Taani dan Banykhaled (2011) yang menyimpulkan bahwa Cash Flow from Operation mempunyai pengaruh yang signifikan dan positif terhadap Earning Per Share pada Amman Stock Market. Berdasarkan penelitian terdahulu, maka dapat ditarik hipotesis sebagai berikut:

$\mathbf{H}_{3}$ :Terdapat pengaruh yang positif dan signifikan dari cash flow from operation terhadap earning per share.

\section{METODE}

Sampel yang dipilih dari seluruh perusahaan manufaktur yang terdaftar di BEI antara tahun 20092011. Penarikan sampel dilakukan dengan metode purposive sampling menggunakan kriteria tertentu. Kriteria yang digunakan adalah sebagai berikut: (1) Perusahaan - perusahaan tersebut bergerak pada industri manufaktur yang terdaftar di Bursa Efek Indonesia selama periode pengamatan; (2) Penelitian dilakukan pada sahamsaham perusahaan manufaktur yang selalu menghasilkan earning per share yang positif; (3) Memiliki data laporan keuangan yang lengkap selama periode pengamatan.

Terdapat 139 perusahaan manufaktur yang terdaftar pada Bursa Efek Indonesia (BEI) selama periode 2009-2011. Untuk lebih jelasnya dapat dilihat pada table berikut ini.

Tabel 1. Pemilihan Sampel

\begin{tabular}{lc}
\hline Jumlah perusahaan manufaktur yang terdaftar di & 139 \\
BEI tahun 2009-2011 & \\
\hline Jumlah perusahaan manufaktur yang delisted dari & 3 \\
BEI tahun 2009-2011 & \\
\hline $\begin{array}{l}\text { Jumlah perusahaan manufaktur yang tidak } \\
\text { menghasilkan earning per share yang positif }\end{array}$ & \\
\hline Jumlah perusahaan manufaktur yang tidak tersedia & 6 \\
laporan keuangannya sepanjang periode 2009-2011 & \\
\hline Jumlah sampel yang diteliti & 75 \\
\hline
\end{tabular}

Variabel yang digunakan dalam penilitian ini terdiri dari: (1) Variabel Terikat (Dependent Variable), dalam penelitian ini adalah return. Indikator yang digunakan untuk mengukur earning per share. Earning Per Share dalam penelitian ini menggunakan hasil perhitungan yang telah dipublikasikan oleh BEI (Bursa Efek Indonesia) selama periode 2009-2011; (2) Variabel Bebas (Independent Variable), variabel bebas dalam penelitian ini adalah kinerja keuangan, firm size dan cash flow from operation dari perusahaan manufaktur yang terdaftar di BEI (Bursa Efek Indonesia) selama periode 2009 - 2011. Kinerja keuangan terdiri dari Net profit margin, Return on equity, Current Ratio, Debt to Equity Ratio, Total asset turnover dan Price to book value. Firm Size di ukur dengan menghitung Log dari Total Aset perusahaan, dan cash flow from operation di hitung dengan menambah laba bersih terhadap bunga di tambah depresiasi lalu dikurangkan dengan pajak.

Tabel 2. Variable Dependent and Independent

\begin{tabular}{clll}
\hline \multicolumn{2}{c}{ Variabel } & \multicolumn{1}{c}{ Indikator } & Skala Pengukuran \\
\hline Dependent & Return & Earning Per Share & Skala Rasio \\
\hline & Profitability & Net Profit Margin (NPM) & Skala Rasio \\
& Profitability & Return on Equity (ROE) & Skala Rasio \\
& Liquidity & Current Ratio (CR) & Skala Rasio \\
Independent & Leverage & Debt to Equity Ratio (DER) & Skala Rasio \\
& Turnover & Total Asset Turnover (TATO) & Skala Rasio \\
& Market Ratio & Price to Book Value & Skala Rasio \\
& Size & Total Asset & Skala Rasio \\
& Cash Flow & Cash flow from operation & Skala Rasio \\
\hline
\end{tabular}




\section{Metode Analisis Data}

Analisis statistik deskriptif dalam penelitian ini merupakan analisis yang memberikan gambaran secara umum mengenai setiap variabel yang sedang di teliti. Statistik deskriptif dalam penelitian ini terdiri dari nilai minimum, nilai maksimum, nilai rata-rata, dan nilai standar deviasi.

\section{Metode Regresi Linier Berganda}

Metode analisis data dalam penelitian ini adalah regresi linier berganda yang digunakan untuk mengetahui pengaruh antara Rasio Keuangan, Firm Size dan Cash Flow from Operation terhadap Earning Per Share. Analisis ini dilakukan secara simultan untuk mengetahui pengaruh seluruh independent variable yaitu Rasio Keuangan, Firm Size dan Cash Flow from Operation terhadap Earning Per Share (laba per lembar saham).

Persamaan regresi yang digunakan untuk melihat pengaruh antara independent dan dependent variable dalam penelitian ini adalah sebagai berikut:

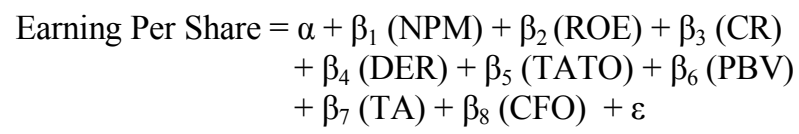

Keterangan:

$\alpha \quad$ : Konstanta

$\beta_{1}$ : Koefisien regresi terhadap net profit margin

NPM : Variabel independent net profit margin

$\beta_{2} \quad$ : Koefisien regresi terhadap return on equity

ROE : Variabel independent return on equity

$\beta_{3} \quad$ : Koefisien regresi terhadap current ratio

$\mathrm{CR}$ : Variabel independent current ratio

$\beta_{4} \quad$ : Koefisien regresi terhadap debt to equity ratio

DER : Variabel debt to equity ratio

$\beta_{5} \quad$ : Koefisien regresi terhadap total asset turnover

TATO : Variabel independent total asset turnover $\beta_{6} \quad$ : Koefisien regresi terhadap price to book value

PBV : Variabel independent price to book value

$\beta_{7} \quad$ : Koefisien regresi terhadap total asset

TA : Variabel independent total asset

$\beta_{8} \quad$ : Koefisien regresi terhadap cash flow from operation

$\mathrm{CFO}:$ Variabel independent cash flow from operation

$\varepsilon \quad$ : error term model

Tabel 3. Profil 75 Perusahaan yang memenuhi Kriteria Pengambilan Sampel

\begin{tabular}{lcc}
\hline \multicolumn{1}{c}{ Sub Sektor } & $\begin{array}{c}\text { Jumlah yang memenuhi } \\
\text { syarat }\end{array}$ & Persentase dari Total Sampel \\
\hline Animal Feed & 4 perusahaan & $5,33 \%$ \\
Automotive and & 11 perusahaan & $14,67 \%$ \\
Components & Cable & \\
Cement & 3 perusahaan & $4 \%$ \\
Ceramics, Glass, Porcelain & 2 perusahaan & $4 \%$ \\
Chemicals & 6 perusahaan & $2,67 \%$ \\
Cosmetics and Household & 2 perusahaan & $8 \%$ \\
Food and Beverages & 10 perusahaan & $2,67 \%$ \\
Houseware & 1 perusahaan & $13,33 \%$ \\
Metal and Allied Products & 9 perusahaan & $1,33 \%$ \\
Pharmaceuticals & 7 perusahaan & $12 \%$ \\
Plastics and Packaging & 7 perusahaan & $9,33 \%$ \\
Pulp and Paper & 3 perusahaan & $9,33 \%$ \\
Textile, Garment & 4 perusahaan & $4 \%$ \\
Tobacco Manufacturers & 3 perusahaan & $5,33 \%$ \\
\hline \multicolumn{1}{c}{ Jumlah } & 75 perusahaan & $4 \%$ \\
\hline Sumber: Datahasilpengolahan & & $\mathbf{1 0 0 \%}$
\end{tabular}

\section{HASIL DAN PEMBAHASAN}

\section{Deskripsi Objek Penelitian}

Penelitian ini menggunakan data keuangan dari tahun 2009 hingga tahun 2011 pada industri manufaktur milik pemerintah, swasta domestik, dan swasta asing yang tercatat di Bursa Efek Indonesia (BEI), serta memiliki data laporan keuangan yang lengkap selama periode pengamatan. Terdapat 139 perusahaan manufaktur yang terdaftar pada Bursa Efek Indonesia (BEI) selama periode 2009-2011.
Perusahaan manufaktur tersebut terdiri dari beberapa sub sektor seperti: sub sektor cement sebanyak 3 perusahaan, sub sektor ceramics, glass, and porcelain sebanyak 6 perusahaan, sub sektor metal and allied products sebanyak 18 perusahaan, sub sektor chemicals sebanyak 10 perusahaan, sub sektor plastics \& packaging sebanyak 12 perusahaan, sub sektor animal feed sebanyak 4 perusahaan, sub sektor wood industries sebanyak 2 perusahaan, sub sektor pulp \& paper sebanyak 8 perusahaan, sub sektor automotive and components 
sebanyak 12 perusahaan, sub sektor textile (garment) sebanyak 19 perusahaan, sub sektor footwear sebanyak 3 perusahaan, sub sektor cable sebanyak 6 perusahaan, sub sektor electronics sebanyak 1 perusahaan, sub sektor food and beverages sebanyak 15 perusahaan, sub sektor tobacco manufacturers sebanyak 3 perusahaan, sub sektor pharmaceuticals sebanyak 10 perusahaan, sub sektor cosmetics and household sebanyak 4 perusahaan, dan sub sektor houseware sebanyak 3 perusahaan.

Dari pemaparan di atas terdapat 3 perusahaan manufaktur yang delisted selama periode 2009-2011, terdapat 45 perusahaan yang tidak menghasilkan earning per share yang positif, serta terdapat 6 perusahaan yang tidak tersedia laporan keuangannya selama periode penelitian ini. Maka setelah melalui proses pemilihan dan evaluasi kelengkapan data, maka didapatkan 75 perusahaan yang layak diteliti.

\section{Analisis Statistik Deskriptif}

Tabel 4. Statistik Deskriptif 75 Perusahaan Manufaktur Periode 2009 - 2011

\begin{tabular}{lrrrr}
\hline \multicolumn{1}{c}{ VARIABEL } & \multicolumn{1}{c}{ MIN } & \multicolumn{1}{c}{ MAX } & \multicolumn{1}{c}{ MEAN } & \multicolumn{1}{c}{ STD. DEV. } \\
\hline Earning Per Share (Rp) & 0,69 & $24.080,78$ & 871,72 & 2742,72 \\
Net Profit Margin (\%) & 0,08 & 35,31 & 7,84 & 6,58 \\
Return On Equity (\%) & 0,75 & 449,09 & 25,76 & 34,61 \\
Current Ratio (\%) & 29,17 & $1.174,28$ & 240,12 & 185,29 \\
Debt to Equity Ratio (X) & 0,08 & 10,16 & 1,22 & 1,47 \\
Total Asset Turnover (X) & 0,36 & 5,65 & 1,33 & 0,67 \\
Price to Book Value (X) & 0,13 & 35,45 & 2,16 & 3,15 \\
Total Asset (Jutaan Rp) & 69.784 & 153.521 .000 & $5.440 .249,77$ & 15506808,51 \\
Cash Flow from Operation (Jutaan Rp) & 2.325 & 17.832 .000 & $848.239,12$ & 2287908,21 \\
\hline
\end{tabular}

Sumber: Data diolah dengan program SPSS 16

\section{Pembahasan Hasil Penelitian}

Tabel 5. Hasil Signifikansi Regresi

\begin{tabular}{cllccc}
\hline No & & \multicolumn{1}{c}{ Variabel } & Coeff. Beta & Sig. & Pengaruh \\
\hline 1 & Rasio & Net Profit Margin & 0,101 & 0.000 & Signifikan \\
& Keuangan & Return On Equity & 0,005 & 0.002 & Signifikan \\
& & Current Ratio & 3,11400 & 0.756 & Tidak Signifikan \\
& & Debt to Equity Ratio & 0,023 & 0.292 & Tidak Signifikan \\
& & Total Asset Turnover & 0,263 & 0.000 & Signifikan \\
& & Price to Book Value & $-0,04$ & 0.272 & Tidak Signifikan \\
2 & Firm Size & Total Asset & 0,337 & 0.000 & Signifikan \\
3 & Cash Flow & Cash Flow from Operation & $-2,207$ & 0.081 & Tidak Signifikan \\
\hline
\end{tabular}

Sumber: Data diolah dengan program SPSS 16

\section{Pembahasan Hipotesis 1}

Berdasarkan tabel 4 di atas, ditemukan bahwa pada tingkat alpha 5\% rasio likuiditas, rasio hutang, dan rasio pasar yang diwakili oleh variabel current ratio, debt to equity ratio, dan price to book value tidak memiliki pengaruh yang signifikan terhadap earning per share. Hasil ini dibuktikan dengan pengujian uji t dengan tingkat kepercayaan $95 \%$. Hal ini bertentangan dengan hasil penelitian yang dilakukan Taani dan Banykhaled pada Amman Stock Market yang menyimpulkan bahwa price to book value dan debt to equity ratio berpengaruh secara signifikan terhadap earning per share. Begitu pula dengan Dwi et al (2009) yang menyimpulkan market ratio berupa price to book value berpengaruh positif signifikan dan juga penelitian Pouraghan et al (2013) yang menemukan bahwa current ratio, debt to equity ratio, dan market value to book value ratio berpengaruh positif signifikan terhadap earning per share pada Tehran Stock Exchange.

Rasio likuiditas dalam penelitian ini terbukti tidak signifikan mempengaruhi earning per share karena likuiditas merupakan suatu indikator mengenai kemampuan perusahaan untuk membayar semua kewajiban financial jangka pendek pada saat jatuh tempo dengan menggunakan aktiva lancar yang tersedia. Dengan demikian semakin tinggi current ratio akan dapat menurunkan earning per share perusahaan (Djarwanto, 2011). Rasio hutang tidak signifikan mempengaruhi earning per share karena tidak terciptanya struktur modal yang optimal yang dapat memaksimumkan earning per share (Brigham dan Houston, 2012). Demikian pula dengan rasio pasar yang tidak signifikan dikarenakan Price 
to Book Value yang rendah merupakan investasi yang aman serta memungkinkan untuk memperoleh keuntungan lebih besar dikarenakan potensi yang masih bisa ditingkatkan (Tjiptono dan Hendy, 2011).

Dari hasil penelitian ini, variabel ditemukan bahwa rasio profitabilitas yang di ukur dengan menggunakan net profit margin dan return on equity berpengaruh secara signifikan positif terhadap earning per share. Artinya dengan meningkatkan rasio profitabilitas/profitabiliy ratio yaitu net profit margin dan return on equity dapat meningkatkan earning per share. Hal ini dikarenakan nilai earning per share suatu perusahaan akan meningkat apabila persentase kenaikan laba bersihnya lebih besar daripada persentase kenaikan jumlah saham yang beredar (Weston dan Weaver, 2008). Demikian pula dengan rasio aktivitas yang di ukur menggunakan total asset turn over berpengaruh secara signifikan terhadap earning per share. Dengan meningkatkan rasio aktivitas (turnover ratio/activity ratio) dapat mempengaruhi earning per share. Tingkat aktivitas menunjukkan kemampuan perusahaan dalam memutar sumber dayanya. Semakin tinggi perputaran sumber daya tersebut menunjukkan kalau tingkat aktivitas perusahaan semakin tinggi. Sebagai hasilnya tingkat efisiensi, dapat dicapai dan ini akan meningkatkan laba yang pada akhirnya berdampak pada Earning Per Share pada perusahaan yang bersangkutan (Husnan dan Pudjiastuti, 2012). Hal ini sejalan dengan hasil penelitian sebelumnya yang telah dilakukan oleh Pouraghajan et. Al (2013) yang menyimpulkan bahwa net profit margin, return on equity, debt to equity ratio, total asset turnover, dan total asset mempengaruhi earning per share secara signifikan. Taani dan Banykhaled (2011) menyimpulkan return on equity berpengaruh signfikan terhadap earning per share dan juga Dwi et Al. (2009) yang menyimpulkan pula net profit margin, return on equity, total asset turnover secara signifikan mempengaruhi earning per share.

\section{Pembahasan Hipotesis 2}

Berdasarkan tabel 4 di atas, ditemukan bahwa pada tingkat alpha $5 \%$ variabel firm size terbukti secara signifikan mempengaruhi earning per share. Hal ini sekaligus memperkuat hasi penelitian sebelumnya yaitu penelitian Ruwanti, dan Devina (2012), Daniati dan Suhairi (2006), serta Johnson et al (2003) yang semuanya menyimpulkan bahwa firm size berpengaruh signifikan terhadap earning per share. Firm size berpengaruh signifikan terhadap earning per share. Artinya, dengan ditingkatkannya firm size maka nilai earning per share perusahaan tersebut akan mengalami peningkatan pula. Perusahaan yang besar dianggap mempunyai risiko yang lebih kecil, karena perusahaan yang besar dianggap lebih mempunyai akses ke pasar modal sehingga lebih mudah untuk mendapatkan tambahan dana yang kemudian dapat meningkatkan profitabilitas (Elton dan Gruber, 2009).

\section{Pembahasan Hipotesis 3}

Berdasarkan tabel 4 di atas, ditemukan bahwa pada tingkat alpha 5\% variabel cash flow from operation tidak mempengaruhi earning per share secara signifikan. Hal ini bertentangan dengan hasil penelitian yang dilakukan sebelumnya oleh Pradhono dan Yulius (2004), Daniati dan Suhairi (2006), Triyono dan Hartono serta Taani dan Banykhaled (2011) dengan hasil penelitian ditemukan pengaruh signifikan dari cash flow from operation terhadap earning per share (return). Cash flow from operation tidak berpengaruh signifikan terhadap earning per share. Dikarenakan kontribusi Cash flow from operation terhadap laba bersih kurang signifikan (Pradhono dan Yulius, 2004). Artinya, dengan meningkatkan cash flow from operation maka nilai earning per share perusahaan tidak akan mengalami perubahan secara signifikan hal ini sesuai dengan penelitian dari Pouraghan et al (2013) dan Dwi et al (2009).

\section{SIMPULAN DAN SARAN}

\section{Simpulan}

Penelitian ini dilakukan untuk mengetahui pengaruh antara kinerja keuangan (NPM,ROE, CR, DER, TATO, PBV), firm size, cash flow from operation terhadap earning per share pada perusahaan manufaktur yang terdaftar di Bursa Efek Indonesia pada tahun 2009-2011. Berdasarkan hasil analisis dan pembahasan yang telah dilakukan, dapat di tarik kesimpulan bahwa Net Profit Margin, Return On Equity, Total Asset Turn Over, dan firm size berpengaruh positif terhadap EPS. Hasil penelitian ini diharapkan dapat diterapkan oleh investor dan manajer keuangan.

\section{Implikasi Manajerial}

Adapun implikasi manajerial dari penelitian ini adalah sebagai berikut:

\section{Bagi Investor}

Mempermudah para investor dalam melakukan investasi dan menentukan perusahaanperusahaan apa saja yang mempunyai prospek yang menguntungkan dengan menggunakan rasio profitabilitas, rasio aktivitas, dan firm size. 
Dikarenakan ketiga indikator tersebut terbukti mempengaruhi earning per share, sehingga dengan earning per share yang baik maka investor berpotensi untuk memperoleh return yang lebih besar (Tjiptono dan Hendy, 2011).

2. Bagi Perusahaan

Manajer keuangan dapat memanfaatkan dan memperhatikan rasio profitabilitas, rasio aktivitas, dan firm size. Dengan tujuan meningkatkan nilai eTotal asset Turn Over, arning per share mereka yang pada akhirnya dapat menarik minat para investor untuk memilih berinvestasi pada perusahaan mereka (Lasher, 2010).

\section{DAFTAR PUSTAKA}

Alexandri, M. Benny. 2008. Manajemen Keuangan Bisnis. Cetakan Kesatu. Bandung: Alfabeta.

Brigham, Eugene F., Houston Joel F. 2012. Fundamentals of Financial Management. 13th Edition. SouthWestern Cengage Learning.

Daniati, N. dan Suhairi. 2006. Pengaruh Kandungan Informasi Komponen Laporan Arus Kas, Laba Kotor, dan Size Perusahaan terhadap Expected Return Saham. SNA IX Padang, hal. 1-23.

Dewi, K.S. Prasetiono. 2012. Analisis Pengaruh ROA, NPM, DER, dan SIZE terhadap Praktik Pemerataan Laba. Diponegoro Journal of Management, Vol. 1, No. 2, hal. 172-180.

Djarwanto. 2011. Pokok-pokok Analisis Laporan Keuangan. Edisi 4, Cetakan Pertama, Yogyakarta: BPFE.

Dwi Martani, Mulyono, Rahfiani Khairurizka. 2009. The Effect of Financial Ratios, Firm Size, and Cash Flow from Operating Activities in Interim Report to the Stock Return, Chinese Business Review, Vol.8, no.6, hal. 44-53.

Elton, E. J. dan Gruber M. J. 2009, Modern Portfolio Theory And Investment Analysis, 8th Edition, John Wileys \& Sons, New York.

Gitman, L. J. dan Zutter C.J. 2012. Principals of Managerial Finance. 13th Edition. Pearson-Prentice Hall, New Jersey.

Husnan, S. dan Pudjiastuti E. 2012. Dasar-Dasar Teori Portofolio dan Analisis Sekuritas. Edisi 5. UPP-AMP YKPN, Yogyakarta.

Johnson, Robert, S. Luc, 2003. Indicator of Successful Companies. European Management Journal, Vol. 21 No. 3, hal. 364-369.

Lasher, William. 2010. Practical Financial Management. 6th Edition. South-Western Cengage Learning, Canada.
Nikolai, Loren A., Bazley, J. D., Jones, J. P. 2010. Intermediate Accounting. 11th Edition. SouthWestern Cengage Learning, Canada.

Pancawati J., Pramuka B. A., Jaryono. 2004. Analisis Variabel yang Mempengaruhi Earning Per Share (EPS) pada Perusahaan Manufaktur yang Tercatat di Bursa Efek Jakarta. SMART, Vol. 1, No. 1, hal. 45-56.

Pouraghajan, Abbasali, E. Mansourinia, S.M.B. Bagheri, M. Emamgholipour, B. Emamgholipour. 2013. Investigation the Effect of Financial Ratios, Operating Cash Flows and Firm Size on Earning Per Share: Evidence from the Tehran Stock Exchange. International Research Journal of Applied and Basic Sciences, Vol. 4, No. 5, hal. 1026-1033.

Pradhono, C. dan Yulius J. 2004. Pengaruh Economic Value Added, Residual Income, Earnings dan Arus Kas Operasi terhadap Return yang diterima oleh pemegang saham. Jurnal Akuntansi dan Keuangan Vol. 6 No.2 hal 140-166.

Reilly,F.K.Brown,K.Cates.2012. Investment Analysis and Portfolio Management. 10th Edition. South-Western Cengage Learning, USA.

Ruwanti, Gemi. dan Devina, Felicia, 2012. Analisis Variabel-variabel Struktur Modal dan Pengaruhnya terhadap Laba per Lembar Saham (EPS) pada Perusahaan Manufaktur yang Terdaftar di Bursa Efek Indonesia. Jurnal Manajemen dan Akuntansi, Vol. 13, No. 1, hal. 17-24.

Sugiono, Arief, 2009. Manajemen Keuangan untuk Praktisi Keuangan, Grasindo, Jakarta.

Syafri, H. Sofyan, 2008. Analisa Kritis atas Laporan Keuangan, PT. Raja Grafindo Persada, Jakarta.

Syamsuddin, Lukman, 2009. Manajemen Keuangan Perusahaan, PT. Raja Grafindo Persada, Jakarta.

Taani, K. Banykhaled M.H.H. 2011. The Effect of Financial Ratios, Firm Size and Cash Flows from Operating Activities on Earnings Per Share. International Journal of Social Science and Humanity Studies, Vol. 3, No. 1, hal. 197-205.

Tandelilin, Eduardus. 2010. Portofolio dan Investasi. Edisi 1. Kanisius, Yogyakarta.

Tjiptono, D. dan Hendy M. F. 2011. Pasar Modal di Indonesia. Edisi 3. Salemba Empat, Jakarta.

Triyono dan Hartono J., 2000, Hubungan Kandungan Informasi Arus Kas, Komponen Arus Kas dan Laba Akuntansi dengan Harga atau Return Saham, Jurnal Riset Akuntansi Indonesia, Vol. 3, No. 1, hal: 54-68.

Weston, J. Fred, S. C. Weaver. 2008. Strategic Financial Management. 1st Edition. Thomson South-West, USA.

Whittington, O. Ray, P. R. Delaney. 2011. Wiley CPA Examination Review. 38th Edition. John Wiley \& Sons, Illinois. 